KOHL, MARGARET (ED.)

JÜRGEN MOLTMANN: COLLECTED READINGS

MINNEAPOLIS: FORTRESS PRESS, 2014. PP. V-295.

PAPERBACK. \$34.00. ISBN 978-0-8006-9989-5

\title{
Jonathan Huggins
}

Berry College, Mount Berry, Georgia

Stellenbosch University, Stellenbosch, South Africa

\section{CONTACT DETAILS}

Jonathan Ray Huggins, Ph.D.

Research Associate at the University of Stellenbosch, South Africa.

Berry College, 2277 Martha Berry HWY, Mount Berry, GA 30149.

Privaatsak X1, Matieland, Suid-Afrika, 7602

jhuggins@berry.edu

Margaret Kohl has provided us with a great gift. A translator of a number of Jürgen Moltmann's works, she has chosen significant selections from eight of his major works and put them together in one volume, adding her own brief introductions to each. The result is a stellar introduction to one of the most influential theologians of the twentieth and twenty-first centuries.

Moltmann's publications span approximately fifty years. The works introduced here include Theology of Hope (1964), The Crucified God (1972), The Trinity and the Kingdom (1980), God in Creation (1985), The Way of Jesus (1989), The Spirit of Life (1991), The Coming of God (1995), and Ethics of Hope (2010).

Richard Bauckham writes a helpful introduction to the book that properly orients the reader into Moltmann's thought. He writes:

"Moltmann's work sought to restore the full dimensions of Christian hope. (He) showed how the biblical history of promise projects a new future for this world and its history. Within the horizon of God's coming renewal of God's whole creation there was plenty of room for proximate hopes of social and political transformation, awakened and sustained by ultimate hope. This was a programmatic reorientation of theology that, in a single move, turned the church toward both the future and the world"(1).

Bauckham believes that "it would be hard to exaggerate" Moltmann's influence in this theological move toward transformation. That assessment appears to be correct in regard to both Moltmann's past influence and his current role in continuing to shape theological discussion. If Moltmann were no longer relevant, it is hard to 
imagine Fortress Press wanting to publish a collection of his works now. In fact, many of Moltmann's themes remain as important and relevant today as they ever were (Trinitarianism, eschatology, soteriology, and pneumatology), and some are even more urgent (ecology, human dignity, and ethics).

Bauckham helpfully suggests three important themes for readers to look for in Moltmann's work. Firstly, "passion," by which he means Moltmann's emphasis on God's passionate love and concern, "his committed and costly involvement with the world"(4). Secondly, "mutuality and perichoresis," by which he means Moltmann's emphasis on God's Trinitarian life as "an intimate reciprocity of loving relationships"(4). This establishes both that God is love (a love that is open and inviting rather than closed) and that mutuality rather than hierarchy should characterize relationships. And thirdly, "life," which refers to Moltmann's work on the Holy Spirit, which in turn leads to "a love of life and an affirmation of all life"(6). These three themes together demonstrate "Moltmann's characteristic concern for a theology of positive involvement in the world"(6). Such emphases remain as relevant and necessary in today's world as ever.

The contents and arguments from each individual volume by Moltmann have been examined and commented upon in detail for many years by many leading scholars. I do not intend to address those contents here. Rather, as a review of the collection, I want to inform readers that this volume makes for an excellent introduction into Moltmann's theology. The book provides just enough of each work to educate the reader on the basic ideas, as well as enough to draw them to the larger individual works for more.

Kohl's introductions to each work provide the necessary details to help a reader understand some of the historical and theological contexts. They also mention some of the main ideas that readers should look for when they engage each work. For instance, to introduce Theology of Hope, she informs the reader that the work was published in 1964, made an "immediate and astonishing impact," was partly a response to Marxist philosopher Ernst Bloch's Principle of Hope. She also informs the reader that this work demonstrated the relevance of eschatology. For a long time, eschatological hope was viewed as applying only to life after this present world. But Moltmann argued that Christianity was about "hope and promise from the beginning"(7). This hope was for the present world, not just hereafter, and was established by the resurrection of Christ. Kohl includes here an excerpt from Moltmann's autobiography, A Broad Place, wherein he states, "three key concepts (that) are essential for every Christian theology of hope:

1. The concept of the divine promise in the Old Testament; 
2. The concept of the raising of the crucified Christ as God's future for the world, in the New Testament;

3. An understanding of human history as the mission of the kingdom of God today" (7, quoting A Broad Place, 101).

By including such details in the introduction, Kohl has set the reader up for success in getting the most out of his or her reading. Altogether, this resource provides an excellent introductory textbook for a course, or as part of a course, on Moltmann, specifically, or on Modern Theology, more generally.

This is the place to begin studying Moltmann's work, and the first text to give students just beginning what is sure to be a life-long engagement with this master theologian. I would put the book in the hands of every aspiring theology, or philosophy, student. I would also recommend it to all Christian ministers in the various churches. Moltmann's work is of such value that every level of teacher in and for the church must engage it. 